\title{
COGNITIVE-BEHAVIORAL THERAPY UNTUK MENANGANI KEMARAHAN PELAKU BULLYING DI SEKOLAH
}

\author{
Erna Hervina Ahmad ${ }^{1)}$ \\ ${ }^{1)}$ Magister Bimbingan Konseling, Universitas Negeri Jakarta, Indonesia \\ E-mail:Erna.hervinaahmad@gmail.com
}

\begin{abstract}
Abstrak. Maraknya tindakan bullying yang terjadi di lingkungan sekolah saat ini sudah sangat memprihatinkan. Salah satu dampak yang ditimbulkan menyasar pada pelaku, yaitu adanya indikasi yang menggambarkan perilaku agresif yang lebih besar/meningkat dikemudian hari yang dilakukan oleh pelaku. Pemberian intervensi yang efektif bagi pelaku bullying harus didasarkan pada bagaimana kondisi emosinya. Emosi yang melatarbelakangi remaja melakukan tindakan bullying adalah emosi marah. Sedangkan rasa marah yang dimiliki remaja pelaku bullying ialah karena adanya distorsi pada cara berpikirnya. Pelaku bullying akan beranggapan negatif pada setiap situasi yang dirasa mengancam dirinya kemudian jalan keluar yang dapat ia lakukan dalam mengatasi ancaman itu ialah dengan melakukan tindak kekerasan. Dengan adanya distorsi kognitif pada diri pelaku bullying maka pendekatan yang dianggap sesuai adalah cognitivebehavioral therapy (CBT). Asumsi dasar pendekatan CBT adalah bahwa tingkah laku yang ditampilkan dipengaruhi oleh proses kognitif. Jadi dengan CBT, intervensi tidak hanya berfokus pada perubahan tingkah laku (tindakan bullying) akan tetapi mengintervensi pula proses kognitif yang mempengaruhi emosi dan tingkah laku.
\end{abstract}

Kata Kunci: Bullying; Emosi Marah; Cognitive-Behavioral Therapy

\section{Pendahuluan}

Tindakan bullying yang terjadi di lingkungan sekolah saat ini sudah sangat memprihatinkan. Menurut KPAI [1] dari tahun 2011 hingga Agustus 2014 tercatat 369 pengaduan terkait masalah bullying di sekolah. Kurniasari, dkk [2] mengenai bullying di Indonesia bahwa bullying dialami oleh anak-anak yang bersekolah di SD, SMP, SMA. Bentuk perilaku yang dialami oleh anak-anak bersifat verbal seperti dipanggil dengan nama yang tidak diinginkan (SD: 45,2\%; SMP: 44,5\%, SMA: 52,6\%). Dipanggil terkait dengan kepandaian, baik karena terlalu pandai atau karena berprestasi (SD: 32,4\%; SMP 31,6\%; SMA: 42,2\%). Selain itu dalam bentuk fisik, berupa didorong, ditendang, ditekan atau dipukul (SD: 50,3\%; SMP: 45,2\%; SMA; 35,1\%) dan dalam bentuk perundungan emosional seperti difitnah (SD: 3,4\%; SMP: 47,1\%, SMA; 50\%). Selanjutnya, ditemukan bahwa pelaku bullyinglebih banyak dilakukan pada anakanak SMA (14.1\%) daripada anak SMP (12,5\%) dan SD $(9,9 \%)$.

Bullying menurut Donnellan [3] adalah ketika seseorang secara sadar menyakiti, melecehkan dan mengintimidasi orang lain. Menurut Rigby [4] bullying melibatkan keinginan untuk menyakiti, tindakan menyakitkan, ketidakseimbangan kekuatan, penggunaan kekuatan yang tidak adil, dilakukan secara berulang, pelaku merasa senang atas perbuatannya dan perasaan tertindas yang dirasakan korban. Bullying memiliki dampak pada fisik maupun psikologis siswa. Menurut Ilie et al [5] siswa yang menjadi korban bullying baik di sekolah maupun melalui internet mengalami kerusakan otak yang lebih signifikan dibandingkan siswa lain yang tidak menjadi korban bullying. Selain berdampak pada korban, bullying juga berdampak pada pengamat dan pelaku. Bagi siswa lain yang menyaksikan tindakan bullying (pengamat), Rivers, Potetat, Noret, \& Ashurst [6] melihat adanya dampak negatif yang signifikan terhadap kesehatan mental siswa tersebut, meskipun mereka bukan korban atau tidak pernah menjadi korban bullying. Sedangkan bagi pelaku, Hawker \& Boulton [7] menemukan bahwa pelaku bullying beresiko menjadi individu yang memiliki tingkat kemarahan dan depresi yang tinggi, terindikasi untuk terlibat dalam perilaku kriminal saat dewasa nanti dan cenderung tidak memiliki sikap empati.

Melihat dampak yang ditimbulkan maka perlu ada bantuan yang diberikan tidak hanya pada korban, melainkan juga pada pelaku. Alasan yang mendasari pentingnya pemberian intervensi pada pelaku menurut Rigby [4] ialah bahwa pelaku harus diberikan pertolongan bukan hanya karena perilaku mereka mencelakakan orang lain tetapi juga karena kerugian yang mungkin mereka alami konsekuensi dari perilakunya tersebut, misalnya membawa mereka keranah hukum. Pada usia remaja, terlibat dalam kasus hukum dapat menimbulkan rasa trauma yang besar sehingga berpengaruh terhadap masa depannya. Hal lain yang menjadi alasan betapa pentingnya intervensi pada pelaku adalah adanya indikasi yang menggambarkan perilaku agresif yang 
lebih besar/meningkat di kemudian hari yang dilakukan oleh pelaku. Oleh karenanya remaja dengan perilaku bullying harus mendapatkan penanganan yang tepat.

Pemberian intervensi yang efektif bagi pelaku bullying harus didasarkan pada bagaimana kondisi emosinya. Junita, Mamesah, \& Hidayat [8] melakukan studi kasus untuk melihat kondisi emosi pelaku bullying, ditemukan bahwa emosi yang dialami pelaku bullying yang mempengaruhi mereka dalam melakukan bullying adalah emosi marah. Herlambang [9] meneliti gambaran motivasi pelaku melakukan bullying, yaitu bahwa tiga motivasi yang paling umum pada pelaku bullying di tiga kota besar di Indonesia adalah pertama, demi mendapatkan popularitas atau terlihat hebat dan kuat dimata teman-temannya; kedua, adanya rasa tidak suka atau iri pelaku kepada korban; dan ketiga bullying merupakan bentuk pelampiasan emosi dari pelaku pada korban. Eisenbraun [10] telah mengidentifikasi karakteristik siswa yang memiliki kemungkinan melakukan kekerasan dimasa yang akan datang diantaranya adalah tidak dapat mengontrol kemarahan, dan perubahan suasana hati yang cepat. Fakta ini menggambarkan bahwa emosi marah yang tidak dapat dikontrol dengan baik akan menjadi salah satu pemicu terjadinya tindakan bullying. Sehingga intervensi yang diberikan pada pelaku bullying dapat difokuskan pada pengelolaan rasa marah yang dimiliki pelaku.

Rasa marah yang dimiliki remaja sehingga mendorong melakukan tindakan bullying ialah karena adanya distorsi pada cara berpikirnya. Hal ini diutarakan oleh Merrell, Gueldner, Ross, \& Isava [11] bahwa pelaku bullying memiliki distorsi kognitif dan bias persepsi sosial mengenai ancaman yang dirasakan di lingkungan mereka dan melihat bahwa agresi merupakan cara yang efektif untuk memecahkan masalah. Pelaku bullying akan beranggapan negatif pada setiap situasi yang dirasa mengancam dirinya kemudian jalan keluar yang dapat ia lakukan dalam mengatasi ancaman itu ialah dengan melakukan tindak kekerasan. Dengan adanya distorsi kognitif pada diri pelaku bullying maka pendekatan yang dianggap sesuai adalah cognitive-behavioral therapy (CBT). Menurut Beck [12], CBT merupakan terapi yang bertujuan untuk mengubah kognitif atau persepsi klien terhadap masalahnya, dalam rangka melakukan perubahan emosi dan tingkah laku klien. Asumsi dasar pendekatan CBT adalah bahwa tingkah laku yang ditampilkan dipengaruhi oleh proses kognitif. Jadi, dengan CBT intervensi tidak hanya berfokus pada perubahan tingkah laku akan tetapi mengintervensi pula proses kognitif yang mempengaruhi emosi dan tingkah laku.

Berdasarkan pemaparan diatas peneliti hendak melihat bagimana Cognitive-Behavioral Therapy (CBT) digunakan untuk menangani kemarahan pelaku bullying di sekolah dengan menggunakan metode studi kepustakaan. Studi kepustakaan menurut Nazir [13] merupakan teknik pengumpulan data dengan mengadakan studi penelaahan terhadap buku-buku, literatur-literatur, catatan-catatan, dan laporan-laporan yang ada hubungannya dengan masalah yang dipecahkan.

\section{KAJIAN TEORI}

\section{A. BULLYING}

Fenomena bullying yang terjadi di sekolah-sekolah di Indonesia mengacu kepada beberapa pengertian bullying dari beberapa ahli. Menurut Olweus [14], bullying terjadi ketika siswa mendapatkan intimidasi atau menjadi korban tindakan negatif dari satu orang atau lebih siswa secara berulang-ulang. Tindakan negatif yang dimaksudkan adalah seseorang dengan sengaja menimbulkan atau mencoba untuk menimbulkan luka atau ketidaknyamanan pada orang lain. Sedangkan Rigby [4] mendefinisikan bullying sebagai keinginan untuk menyakiti, adanya tindakan menyakitkan, ketidakseimbangan kekuatan, penggunaan kekuatan yang tidak adil, biasanya terjadi secara berulang, adanya kenikmatan yang dirasakan oleh pelaku dan perasaan tertindas korban. Sehingga dapat disimpulkan bahwa bullying merupakan tindakan negatif yang dilakukan oleh seseorang atau sekelompok orang yang lebih kuat dan berpengaruh kepada orang lain yang lebih lemah secara sadar, dengan cara langsung maupun tidak langsung, intensitasnya berulang, baik direncanakan maupun spontan sehingga mengakibatkan terlukanya korban baik secara fisik maupun psikis.

Olweus [14] membagi tiga bentuk bullying yaitu kontak fisik, ucapan atau kata-kata (verbal) dan bentuk lain diluar fisik dan verbal. Lebih lanjut dijelaskan bahwa bentuk bullying secara fisik yaitu memukul, mendorong, menendang, atau menjepit. Bentuk bullying verbal yaitu mengancam, mengejek, menggoda atau memanggil dengan sebutan tertentu. Sedangkan bentuk bullying non-fisik/nonverbal yaitu membuat isyarat pada wajah, menyebarkan rumor atau sengaja mengucilkan seseorang dari kelompok atau menolak untuk memenuhi harapan orang lain. Lebih spesifik The Site.org (dalam [3]) menguraikan bentuk bullying yang saat ini terjadi di lingkungan sekolah yaitu meninggalkan/mengasingkan seseorang dengan mengeluarkannya dari lingkungan pertemanan, pelecehan rasis dan homopobic, dianggap "berbeda", pelecehan seksual dan diskriminasi, diejek mengenai situasi keluarga, dipaksa menyerahkan uang, dan serangan fisik. Selain itu seiring dengan perkembangan teknologi, bullying menemukan bentuk barunya yaitu dengan menggunakan fasilitas internet, pelaku menyebarkan foto atau video yang berisi tindakan kekerasan.

Ciri khas pelaku bullying menurut Olweus [15] adalah adanya agresi mereka terhadap teman sebayanya dan juga sering melakukan tindakan agresi terhadap orang dewasa, baik guru maupun orangtua. Pelaku memiliki pandangan yang positif terhadap kekerasan dibandingkan dengan siswa lain pada umumnya. Pelaku juga bersikap impulsif, memiliki kebutuhan yang kuat untuk mendominasi orang lain, memiliki sedikit empati pada korban dan jika pelaku adalah laki-laki, cenderung memiliki kekuatan fisik yang lebih kuat dibandingkan korban.

Faktor penyebab terjadinya perilaku bullying menurut Rigby [4] dapat diklasifikasikan sebagai berikut (1) adanya kesalahan dalam berpikir, ditunjukan dengan pelaku merasa bisa mendapatkan apa yang mereka inginkan, dan 
melakukan bullying adalah bayarannya; (2) karakter yang dimiliki pelaku yaitu pelaku memiliki tingkat empati yang relatif rendah, sehingga ia tidak merasa terpengaruh ketika korban berada dalam tekanan. Pelaku agresif dan impulsif serta rasa puas yang didapat pada kondisi pasrah/patuh/penaklukan orang lain terhadap dirinya; (3) afiliasi teman sebaya, bullying dianggap sebagai sesuatu yang menyenangkan, terutama jika dilakukan oleh seseorang yang merupakan bagian dari kelompok; (4) pengalaman yang didapat dari lingkungan, adanya pengalaman negatif dengan orang tua/keluarga (perasaan tidak dicintai dan/atau terlalu terkontol) sehingga menimbulkan permusuhan terhadap orang lain. Pengalaman pelaku yang dipengaruhi oleh model agresif, yang didapat dari kehidupan nyata dan/atau dengan melihat video kekerasan.

\section{B. COGNITIVE-BEHAVIORAL THERAPY (CBT)}

Cognitive-Behavioral Therapy (CBT) pada awalnya dicetuskan oleh Aaron Beck sebagai pengembangan dari psikoterapi pada awal 1960.Terapi ini dirancang secara terstruktur, dalam jangka waktu yang singkat, berorientasi pada pemecahan masalah saat ini dengan memodifikasi pikiran dan perilaku disfungsional. Beck [12] menjelaskan bahwa CBT adalah terapi yang bertujuan untuk mengubah kognitif atau persepsi klien terhadap masalahnya, dalam rangka melakukan perubahan emosi dan tingkah laku klien. Stallard [16] menyebutkan bahwa CBT merupakan suatu intervensi yang memperhatikan mengenai proses kognitif yang terjadi pada klien dan bagaimana hubungannya dengan perubahan emosi dan tingkah laku klien. Dengan kata lain, konseling dengan menggunakan pendekatan CBT mendorong konselor mencari berbagai cara untuk menghasilkan/memodifikasi perubahan kognitif klien (pikiran dan keyakinan klien) agar menghasilkan perubahan emosi dan pada akhirnya memunculkan perilaku yang lebih adaptif.

Beck [12] menjelaskan langkah-langkah penting yang secara umum terdapat dalam CBT, yaitu (1) membangun hubungan terapeutik, membangun hubungan terapeutik dilakukan sejak pertemuan pertama merupakan hal yang sangat penting karena kelancaran proses konseling selanjutnya ditentukan oleh bagaimana kesan yang didapat klien pada pertemuan pertama; (2) perencanaan intervensi dan struktur sesi, perencanaan pemberian intervensi dilakukan oleh konselor bahkan sebelum bertemu dengan klien, yaitu dengan melihat data-data yang sudah ada mengenai klien. Perencanaan awal dibuat secara umum mengenai bagaimana sesi konseling akan berjalan untuk selanjutnya jalannya konseling akan bergantung pada gejala yang muncul pada klien; (3) mengidentifikasi dan menanggapi disfungsional kognitif, bagian terpenting dalam pendekatan CBT adalah membantu klien merespon pikiranpikirannya yang tidak akurat atau tidak membantu, seperti misalnya pikiran otomatis dan keyakinan inti yang mendasari perilaku tertentu; (4) fokus pada hal yang positif, klien dengan berbagai permasalahannya cenderung terlalu fokus pada hal yang negatif. Ketika berada pada kondisi tertekan klien secara otomatis memberi penekanan besar pada pengalaman negatif dan gagal dalam mengenali pengalaman yang lebih positif; serta (5) memfasilitasi perubahan kognitif dan perilaku antar sesi (homework).

\section{PEMBAHASAN}

Marah merupakan salah satu bentuk emosi alami yang dimiliki oleh manusia. Menurut Spielberger (dalam [17]) marah merupakan keadaan emosional yang mempengaruhi perasaan dan bervariasi intensitasnya dari yang tingkat mengganggunya ringan sampai kepada berat, serta dikaitkan dengan perubahan pada sistem syaraf. Fernandez [18] menyebutkan bahwa marah pada hakikatnya tidak menyenangkan dan oleh para psikolog disebut sebagai perasaan yang dipandang negatif. Sedangkan Novaco (dalam [17]) menjelaskan marah sebagai emosi negatif yang merupakan hasil dari pengalaman subjektif seseorang terhadap orang lain atau terhadap suatu situasi yang dipersepsikan sebagai keadaan yang tidak menyenangkan. Sehingga dapat disimpulkan bahwa marah merupakan kondisi emosi negatif yang disebabkan oleh pengalaman subjektif seseorang baik terhadap orang lain maupun terhadap keadaan yang tidak menyenangkan sehingga mengakibatkan perubahan kognisi dan psikologis seseorang yang berdampak pada bagaimana hubungannya dengan orang lain atau sebuah keadaan.

Munculnya kemarahan pada remaja tidak terlepas dari perkembangan sosial emosi pada tahap itu. Menurut Collins \& Steinberg [19] perkembangan sosial-emosi dipengaruhi oleh tiga faktor yaitu pertama, perubahan biologis dimana remaja mengalami perubahan-perubahan fisik dan hormonal. Pubertas mempengaruhi perkembangan psikologis dan hubungan sosial remaja bergantung pada jenis kelamin, aspek pubertas, tahap pubertas, waktu dan kecepatan pubertas serta di mana pubertas itu terjadi. Perubahan fisik dan hormonal lebih mudah terlihat pada dampak yang ditimbulkannya seperti bagaimana remaja berinteraksi dengan lingkungan sosialnya. Jadi, kondisi emosi yang tidak stabil sebagai dampak dari adanya perubahan hormonal pada diri remaja dapat terwujud dalam bentuk interaksinya dengan lingkungan. Bentuk interaksi sosial yang ditampilkan, baik positif maupun negatif bergantung pada kemampuan remaja tersebut dalam mengelola emosinya. Kedua, perubahan cara berpikir ditandai dengan kemampuan membuat keputusan yaitu munculnya kemampuan dalam mengeluarkan pendapat dan beradu argumentasi dengan orang tua. Pada usia remaja, pembuatan keputusan dipengaruhi oleh kondisi emosi dan pengaruh sosial. Steinberg \& Scott (dalam [19]) menegasakan bahwa meskipun remaja dan orang dewasa memiliki kemampuan berpikir yang sama namun keduanya memiliki faktor sosial dan emosi yang berbeda, seperti misalnya kerentanan terhadap pengaruh teman sebaya dan kontrol impuls sehingga keputusan yang akan diambil juga tidak sama. Hal ini menyebabkan remaja berani mengambil keputusankeputusan yang beresiko. Ketiga, perubahan definisi sosial bagi remaja yaitu remaja sudah memiliki simbol-simbol yang dapat diartikan bahwa dirinya secara sosial sudah tidak dikatakan sebagai anak-anak. Perubahan definisi sosial ini 
memberi pengaruh pada dinamika interaksi teman sebaya dan fungsi kontrol orangtua.

Berdasarkan pada tahap perkembangan ini maka pendekatan yang digunakan untuk remaja perlu mempertimbangkan aspek perkembangan sosial emosi, baik dalam bentuk strategi maupun keterampilan yang diajarkan. CBT pada remaja menurut Nelson, Finch \& Ghee [20] merupakan terapi yang didalamnya menggunakan berbagai strategi pengendalian diri yang tidak hanya mengajarkan remaja untuk menghambat perilaku agresif melalui penggunaan proses kognitif tetapi juga mengajarkan keterampilan alternatif untuk menghambat bertindak secara agresif. Selain itu, beberapa alasan yang menunjukkan mengapa CBT efektif diberikan pada remaja ialah pertama, CBT mengakui kemandirian remaja, berdasarkan uraian mengenai kondisi emosi remaja, dimana remaja sulit melihat dan menerima pandangan orang lain maka bentuk intervensi yang tepat adalah dengan tidak berada pada posisi yang bertentangan dengan dirinya. Remaja harus merasa bahwa pandangannya didengar dan dihormati. Menentang pandangan remaja hanya mengakibatkan remaja merasa tertekan dan meningkatkan kemungkinan perdebatan.Kedua, CBT mengutamakan kolaborasi, pada masa remaja ketertarikan pada teman sebaya yang dianggap lebih memahami dirinya lebih besar daripada orang yang dianggap lebih tua atau orang yang memiliki otoritas terhadap dirinya. Oleh karenanya penciptaan hubungan kolaborasi dalam CBT lebih memudahkan dalam menggali permasalahan yang sedang ia hadapi. Dalam CBT, setiap kegiatan dan pengembangan homework dirancang secara bersama antara konselor dan klien. Ketiga, penggunaan teknik yang sesuai dengan karakteristik remaja, salah satunya adalah pertanyaan Socrates.Teknik ini sangat membantu karena remaja terkadang tidak terbiasa dengan mengekspresikan keyakinan dan ide mereka. Remaja cenderung merasa bahwa pandangan mereka salah sehingga merasa perlu diberitahu apa yang harus dilakukan. Penggunaan pertanyaan ini berguna untuk mengatasi hambatan ini, dimana remaja dibantu untuk mengeksplorasi, menilai kembali dan menantang keyakinannya.

Penelitian mengenai pendekatan CBT yang digunakan untuk menangani masalah yang berhubungan dengan kemarahan sudah banyak dilakukan. Beck \& Fernandez [21], menguji keefektifan pendekatan CBT dalam menurunkan tingkat kemarahan seseorang dengan metode meta-analisis. Berdasarkan 50 penelitian yang melibatkan 1.640 subjek, ditemukan bahwa CBT dapat menurunkan tingkat kemarahan sebesar 76\%. Isrofin [22] melakukan eksperimen terhadap 5 siswa SMA yang memiliki perilaku agresif yang tinggi dengan memberikan pelatihan pengelolaan marah menggunakan pendekatan CBT. Terlihat ada penurunan frekuensi perilaku agresif siswa sebelum, selama dan setelah mendapat perlakuan. Penelitian serupa dilakukan oleh Merdekasari [23], hasilnya menunjukkan bahwa pelatihan mengelola amarah dengan pendekatan CBT dapat menurunkan perilaku agresi.

CBT memberikan penekanan pada tiga hal yaitu pikiran, emosi dan perilaku.Remaja yang terindikasi melakukan tindakan bullying diketahui memiliki kesalahan dalam berpikir, pendekatan CBT membantu klien mengenali dan mengevaluasi kesalahan berpikirnya dengan teknik restrukturisasi kognitif. Kondisi emosi marah pada pelaku bullying merupakan akibat dari kesalahan berpikir, CBT membantu klien mengelola kemarahan dengan mengenali jenis-jenis emosi, perubahan fisik yang terjadi ketika ia merasa marah dan lalu memberikan teknik-teknik yang dibutuhkan seperti teknik relaksasi. Terakhir, pemberian intervensi pada pelaku bullying fokus pada perilaku. Klien diajarkan untuk dapat memecahkan masalah (problem solving)agar dapat berperilaku lebih adaptif dan diterima oleh lingkungan dengan cara melatihkan perilaku yang diharapkan dengan metode role play.

Secara teori CBT dapat digunakan untuk menangani kemarahan pelaku bullying, selain itu pendekatan CBT pun dianggap sesuai untuk lingkup sekolah, dimana waktu dan sumber daya yang sering terbatas. Mennuti, Christner \& Feeman [24] menyatakan bahwa struktur dan kerangka kerja CBT paralel dengan layanan pendidikan, membuatnya lebih mudah diterima di kalangan pendidik. Struktur CBT, yang berfokus pada psikoedukasi, pengembangan keterampilan, kerja antar sesi (yaitu homework), pengaturan agenda, dan pemantauan kemajuan, selaras dengan sebagian besar kegiatan yang sudah ada di sekolah saat ini. Sehingga guru BK lebih mudah mengaplikasikan teori di lapangan dan memodifikasi pendekatan sesuai dengan karakteristik klien dan lingkungannya. Misalnya, Psikoedukasi yang merupakan tahap pemberian pendidikan pada klien mengenai peta permasalahannya dalam kerangka kerja CBT sama seperti kegiatan belajar mengajar siswa dalam kelas, dapat menggunakan media pembelajaran yang kreatif agar proses pembelajaran mudah dipahami. Pemberian tugas rumah atau homework serupa dengan pemberian tugas dalam dunia pendidikan, yaitu berupa tugas yang diberikan pada siswa diluar jam kegiatan belajar mengajar. Secara teknis Beck [12] menerangkan bahwa CBT telah disesuaikan untuk klien dengan berbagai tingkat pendidikan, budaya dan usia. CBT dapat pula digunakan di lingkup medis, kantor, penjara dan sekolah. Proses terapi dapat dilakukan dalam format individu, kelompok, pasangan maupun keluarga. Durasi setiap sesi adalah 45 menit dengan proses terapi dapat lebih singkat. Hal ini sangat sesuai dengan lingkungan sekolah yang memiliki waktu dan kemampuanyang terbatas baik dari sisi siswa maupun guru BK yang memiliki beban kerja melayani siswa dengan rasio $1: 150$ siswa.

\section{KESIMPULAN}

Bullying merupakan tindakan negatif yang dilakukan oleh seseorang atau sekelompok orang yang lebih kuat dan berpengaruh kepada orang lain yang lebih lemah secara sadar, dengan cara langsung maupun tidak langsung, intensitasnya berulang, baik direncanakan maupun spontan sehingga mengakibatkan terlukanya korban baik secara fisik maupun psikis. Kondisi emosi pelaku bullying yang mempengaruhi tindakannya adalah emosi marah. Emosi marah yang muncul disebabkan oleh adanya distorsi berpikir pelaku. Sehingga intervensi yang tepat ialah intervensi yang 
tidak hanya berfokus pada perubahan tingkah laku akan tetapi mengintervensi pula proses kognitif yang mempengaruhi emosi dan tingkah laku.

Cognitive-Behavioral Therapy (CBT) dapat digunakan untuk menangani kemarahan pelaku bullying di sekolah karena beberapa alasan yaitu (1) CBT efektif untuk digunakan pada anak remaja usia sekolah, karena CBT mengakui kemandirian remaja, mengutamakan kolaborasi dalam proses intervensinya, dan menggunakan teknik yang sesuai dengan karakteristik remaja; (2) Struktur CBT yang berfokus pada psikoedukasi, pengembangan keterampilan, kerja antar sesi (yaitu homework), pengaturan agenda, dan pemantauan kemajuan, selaras dengan sebagian besar kegiatan yang sudah ada di sekolah saat ini. Sehingga membantu guru BK dalam pengaplikasian teori di lapangan dengan segala keterbatasan sumber daya dan waktu yang dimiliki.

\section{DAFTAR PUSTAKA}

[1] Setyawan, D. (2014). KPAI: Kasus Bullying dan Pendidikan Karakter. Diakses dari http://www.kpai.go.id/berita/kpai-kasusbullying-dan-pendidikan-karakter/.

[2] Kurniasari, A., Setiawan, H. H., Murni, R., Roebiyantho, H, Widodo, N., \& Rachman, A. (2017). Stop Perundungan di Sekolah (Kekerasan Terhadap Anak di Sekolah). Jakarta: Pusat Penelitian dan Pengembangan Kesejahteraan Sosial, Kementerian Sosial Republik Indonesia.

[3] Donnellan, C. (2006). Bullying. England: Independence Educational Publishers Cambridge.

[4] Rigby, K. (2003). Stop the Bullying: a Handbook for Schools. Aust Council for Ed Research.

[5] Ilie, G., Mann, R. E., Boak, A., Adlaf, E. M., Hamilton, H., Asbridge, M., ... \& Cusimano, M. D. (2014). Suicidality, Bullying and Other Conduct and Mental Health Correlates of Traumatic Brain Injury in Adolescents. PloS one, 9(4), e94936.

[6] Rivers, I., Poteat, V. P., Noret, N., \& Ashurst, N. (2009). Observing Bullying at School: The Mental Health Implications of Witness Status. School Psychology Quarterly, 24(4), 211

[7] Hawker, D. S., \& Boulton, M. J. (2000). Twenty Years' Research on Peer Victimization and Psychosocial Maladjustment: A MetaAnalytic Review of Cross-Sectional Studies. The Journal of Child Psychology and Psychiatry and Allied Disciplines, 41(4), 441-455.

[8] Junita, J., Mamesah, M., \& Hidayat, D. R. (2015). Kondisi Emosi Pelaku Bullying. INSIGHT: Jurnal Bimbingan dan Konseling, 4(2), 57-63.

[9] Herlambang, A. (2008). Gambaran Motivasi Pelaku Bullying pada Pelajar SMP, SMA dan PT di Tiga Kota Besar di Indonesia. Skripsi. Diunduh dari http://lib. ui. ac. id/opac/ui/detail. jsp.

[10] Eisenbraun, K. D. (2007). Violence in schools: Prevalence, Prediction, and Prevention. Aggression and Violent Behavior, 12(4), 459-469.

[11] Merrell, K. W., Gueldner, B. A., Ross, S. W., \& Isava, D. M. (2008). How effective are School Bullying Intervention Programs? A MetaAnalysis of Intervention Research. School Psychology Quarterly, 23(1), 26.

[12] Beck, J.S. (2011). Cognitive Therapy: Basics and Beyond ( $2^{\text {nd }}$ ed.). New York: Guilford Press.

[13] Nazir, M. (2003). Metode Penelitian. Jakarta: Ghalia Indonesia.

[14] Olweus, D. (1993). Bullying At School: What We Know and What We Can Do Understanding Childern's Worlds. Malden: Blackwell Publishing Ltd.
[15] Olweus, D. (1997). Bully/victim problems in school: Facts and intervention. European journal of psychology of education, 12(4), 495.

[16] Stallard, P. (2002). Think Good-Feel Good: A Cognitive Behaviour Therapy Workbook For Children and Young People. England: JOHN WILEY \& SONS, LTD

[17] DiGiuseppe, R., \& Tafrate, R. C. (2007). Understanding Anger Disorders. New York: Oxford University Press.

[18] Fernandez, E. (2013). Treatments for Anger in Specific Populations: Theory, Application, and Outcome. New York: Oxford University Press.

[19] Collins, W. A., \& Steinberg, L. (2006). Adolescent Development in Interpersonal Context. Handbook Of Child Psychology Sixth Edition. New Jersey: John Wiley \& Sons, Inc.

[20] Nelson III, W. M., Finch, A. J. Jr \& Ghee, A. C. (2006). Anger Management with Children and Adolescents: Cognitive-Behavioral Therapy. Child and Adolescent Therapy Cognitive-Behavioral Procedures ( $3^{\text {rd }}$ ed). New York: Philip C. Kendall and The Guilford Press

[21] Beck, R., \& Fernandez, E. (1998). Cognitive-behavioral therapy in the treatment of anger: A meta-analysis. Cognitive therapy and research, 22(1), 63-74.

[22] Isrofin, B. (2016). Efektivitas Pelatihan Pengelolaan Marah Dengan Pendekatan Kognitive Behavior Modification Untuk Mengurangi Perilaku Agresif Siswa. Jurnal Penelitian Bimbingan dan Konseling, 1(2).

[23] Merdekasari, A. (2012) Pelatihan Manajemen Amarah Dengan Pendekatan Terapi Perilaku Kognitif Pada Perilaku Agresi. Tesis. Universitas Muhammadiyah Surakarta. Surakarta.

[24] Mennuti, R. B., Christner, R. W., \& Freeman, A. (2012). CognitiveBehavioral Interventions in Educational Settings. A Handbook For Practice $\left(2^{\text {nd }} e d\right)$. New York: Routledge. 